\title{
Motivation of Czech Employees by the Balanced Scorecard of the Multinational Company - an Empirical Study
}

\author{
Barbora JANASOVÁ*
}

\section{Introduction}

The paper is an outcome of the research, which aims to find out if employees feel motivated by their balanced scorecards. The research was conducted in the Czech local branch of the big multinational company. In order for the balanced scorecard being efficient, managers and other employees need to feel motivated by the individual parts of the scorecard. For the multinational companies this might be an issue, since the strategic goals as well as measures related to global results might be too far away from the local businesses and local employees.

Balanced scorecard was first described by Kaplan and Norton (1992). Since that, balanced scorecard had developed to a widely used way of performance measurement. The role of balanced scorecard is not only to combine the traditional financial measures with non-financial measures, but also to form a basic framework for an efficient strategic management.

The research was conducted as a survey, which tries to tackle the relationships among the specific parts of the balanced scorecard and the employee motivation. This might help company to put more attention to such measures, which motivate employees the most.

The theoretical foundation related to the measurement of the work effort is known as an asymmetric information problem, in particular the principal-agent model. Principal in this context is the owner (or employer) and the agent is the manager (or employee). Effort of the managers is not observable in the real life, so owners can only observe the financial results and other indicators. Owners can motivate the employees by making their remuneration dependable on the various measures, which form parts of the balanced scorecard.

Ing. Barbora Janasová - PhD student; Department of Financial Accounting and Auditing, Faculty of Finance and Accounting, University of Economics, Prague, W. Churchill Sq. 4, 13067 Prague 3, Czech Republic; <xmrab01@vse.cz>. 


\section{Theoretical background-employee/employer relationship}

Nowadays the vast majority of the bigger companies have split ownership from the management. Owners (or in the microeconomic terms the principals) delegate responsibilities and authorities for the managing the company to the managers (or agents). This situation is described by theory as asymmetric information and principal-agent model. This model describes the behavioral drivers behind the management decisions and motivation. According to the Mankiw and Taylor (2010), the same applies to the employment relationship. Employer is the principal, employee is the agent.

There is one party on each side of the market in the theoretical model: principal, who is proposing the contract, and agent, who is accepting (or not accepting) the contract. If the contract is accepted, agent must behave in line with the conditions of the contract. Agent is typically the party with more (or asymmetric) information. In fact, as stated by Bichler Butler (2007), agent is not only choosing if to accept the contract or not, but he also chooses if to work or shirk. Agent needs to find an optimal contract for each possible effort levels.

Based on the theory, there are two basic situations related to asymmetric information. In the first model, behavior of the agent has a direct influence on principal, however the principal cannot monitor agent's behavior directly. Principal has to rely only on results of agent's behavior. Typical example is the agent's effort to deliver his results. This model is called "hidden action" or "moral hazard". Second model describes the situation, where agent has more/private information even before he signs the contract with principal. Those are "hidden types" and typical examples are management skills and similar competencies.

In reality, modern companies are owned by many small owners (typically owners of the shares). Those owners have usually limited knowledge of the particular business. Additionally, since owning only small part of the company, they are not interested to spend time and effort running the company. They hire a company management to run it. In the simple example let us consider the situation, where there is one owner and one manager. Manager can decide if he would accept the contract. If yes, then he decides how much effort he would put into the running of the company. More effort he makes, bigger the company's profit is. Effort represents time and energy together with various skills put into the job. 
In other words, manager is working in his interest, not in the interest of the owner. Manager is working in the owner's interest only in case there are incentives which lead him to such behavior. In practical implementation, this would be bonuses dependent on the company profit, stock value, cash flows, stock options and others. This is what the balance scorecard is aiming at.

In contrary to the standard microeconomics model, in which there are no private information, existence of moral hazard is causing the market inefficiency. While in the standard microeconomic model we can see the manager as any other input (like capital or labor), with clear existence of the asymmetric information, the manager becomes a unique input. It is not enough to pay for this input the fixed rate as for the capital or working labor. The productivity of the manager would depend on the payment scheme.

There are many management theories. They do not form any comprehensive stream, they had been developing independently. They are influenced by the neoclassical economy. However they do not consider the company to be a lifeless object. They take it as a group of the various subjects. It is acknowledged that owners would maximize their profits (dividends), while managers can have different goals. Some examples of the management models are: Baumol's, Williamson's, Scitovsky's, Marris's. Bearing in mind the limitation of this paper, I cannot go into further details of those models.

Additionally, there are many behavioral theories. Also in those models we can see the influence of the neoclassical theory, namely in the maximization of the certain values of the individuals. In contrary to the standard models, subjects interact in the complicated social environment and uncertainty. Those theories are taking into the account the organizational structure of the companies. Target values are influenced by the various company stakeholders. Major stakeholders are owners, managers, employees, customers, government, etc.

Economic theory describes the various types of motivation of the managers. They would maximize their own profit, their own utility, their own salary and remuneration. Motivation of the managers as well as the employees is driven by the remuneration schemes. Owners are trying to find such scheme that would motivate managers or employees to the highest possible performance. The most commonly used scheme is the balanced scorecard. 
Balanced scorecard exists over 20 years. Its creators are Kaplan and Norton, who had written many articles (Kaplan - Norton, 1992, 1993, 1996a, 2000, 2004a, 2005, 2008a), (Kaplan, 2005, 2010) as well as books (Kaplan - Norton, 1996b, 2001, 2004b, 2006, 2008b).

Additionally, there are also very valuable literature reviews related to balance scorecard, for example (Paranjape - Rossiterand - Pantano, 2006), or more recent one (Saraiva 2011). Comprehensive literature review can be also found in (Petera - Wagner, - Mensik, 2012). And finally, there are also several review articles (Neely - Kennerley - Adams 2007), (Taticchi - Tonelli - Cagnazzo, 2010) or (Taticchi - Balachandranand - Tonelli, 2012) related to performance measurement and balanced scorecard.

\section{Research in the multinational company}

The overall goal of the research was to find out how are the employees, including higher management, motivated by the specific parts of the balance scorecard.

In the researched company the balanced scorecard is applied to vast majority of the office staff. Employees excluded are the direct sales staff and staff on the special service agreements. The scorecard is split into several parts. This is in line with the view of Neely, Gregory and Platts (1995), where they see the balance scorecard at several layers - layer of individual performance measures, layer of performance measures as well as its relationship to the environment in which it operates. Relation between business strategy and managers motivation is also examined by Tayler (2010).

First part of the balanced scorecard is common for all employees under the scorecard scheme. The same scorecard results are applied to the whole multinational company globally, across all the geographical or business boundaries.

The common part consists of several indicators, aiming to be balanced, supporting growth, discipline, operational excellence and environmentally sound performance.

As far as financials are concerned, they contribute by $45 \%$ and are represented by Operational Cash flow and Total Shareholder Return (TSR). Operational cash flow results reflect movements in prices and margins as well as underlying operational performance. TSR is a measure that combines changes in the share price with the dividends, and is regarded as the total financial return to the owner of shares. This measure 
had been questioned as well, as the stock markets seem so unpredictable. On the other hand TSR reflects all the publicly known information about the company. That includes financial numbers, but also the effects of important news and events, which are mirrored in the share price. As such, TSR becomes the simplest and most important reflection of performance for investors to judge the company by. The share price reflects the value that investors believe reflects company's capability to create future returns such as earnings, cash flows, and its dividend payments. In this context, what plays a crucial role is investors' confidence in company's ability to keep performing into the future. When we move from the short-term of volatile share prices then, over longer periods, TSR does reflect a company's underlying financial and competitive performance.

The remaining part of the common scorecard consists of the Operational excellence measures as well as the environmental related measures. Operational excellence measures focus on the drivers of business performance that have an impact on how company is viewed and are directly affected by how well people do their jobs. On the other hand performance related to environment is a key one for the sustainable development. More than ever before, investors are concerned about responsibility to safety, social and environmental performances.

The second part of the scorecard is based on the individual performance of each employee. At the beginning of the year each employee is given the set of goals to deliver. Those goals are aimed to be concrete, measurable and achievable. In certain cases, the goals needs to be flexible and should include possibility to deviate if the circumstances changes. The goals set should reflect the most important goals which are in line with the overall company's philosophy. The most critical part of the scorecard is the measurement of the individual goals delivery. Many of the goals cannot be expressed in the monetary terms. They need to be measured by another individuals, line managers or higher management. This brings subjective view into the equation. In general, this subjective view is widely accepted if it respects the same rules for each employee. In the researched company, each employee is valued by his line manager with the coefficient between 0 and 2. On average, wide group of employees performance should be valued as 1 . Line manager is only proposing the value of this measure; final approval is given by the next level management. This is to ensure that the various teams are evaluated in a consistent manner. Additionally same approach is taken across all management levels, all businesses as well as all geographical territories. Final factor 
for each employee serves as a multiple of percentage of the current salary. The percentage of the salary is known in advance, is not changing frequently and is taking into account the local market conditions.

In addition to the more general goals, some of the employees are given so called KPIs (key performance indicators). Those are measures, which are easily calculated, are produced mostly on monthly basis and form the part of the overall individual performance factor. Example of a KPI for finance employee would be provision of certain report on time on working day 6. Those KPIs are typically used for the lower positions. Middle or higher management rarely have those detailed KPIs assigned to them.

Additionally, as part of the stakeholder management, company is using so called People survey to identify the satisfaction of the employees with the management, with the local operations as well as with the global company and global management.

\section{Empirical findings}

Research was conducted in the local branch of the big multinational company. Local branch has around 106 employees. After deduction of the employees who are not on the standard balanced scorecard scheme (direct sales staff, staff on maternity, etc.) I was left with 60 employees being on balance scorecard. The research was conducted via the survey. I have received the replies from 34 respondents, which implies the respond rate of $57 \%$.

I have deliberately selected the timing of my research in the period, which is right after the announcement of the balanced scorecard results. This ensures people have it fresh in their minds and are in a better position to evaluate their feelings around motivation.

The survey consists of 18 questions divided into the 5 major parts. The first part related to global scorecard financial measures, the second part related to global scorecard environment related measures, the third part related to individual performance measures, the fourth part related to individual motivation and the last part related to stakeholder management - company own people survey.

The responses had been valued separately for some responded groups - women, men, and high management. Women formed $35 \%$ of all respondents, men $65 \%$. Higher management formed $24 \%$ and included both women and men. 
Results related to the group scorecard shows that the vast majority of respondents $(65 \%)$ do not feel motivated by the group financial indicators, such as total shareholder value and the cash flow. However, at the same time, the majority of respondents would not like to take out those indicators of the overall balanced scorecard, in fact only $15 \%$ would exclude them from the scorecard. Majority claims to understand the importance of those measures for the group as a whole. The interesting is the division of the answers between men and women. While men are very clear on the position to leave the group indications in the scorecard, women are more neutral in this opinion. Higher management answers are in line with the men section, despite the fact, that there are $25 \%$ of women in the higher management. It is worth to notice, that women have more aligned answers among themselves, compared to men, where the standard deviation is higher, especially when it comes to the opinion, if to include the group financial scorecard in the overall package or not. The detailed results of this section are shown in the Tab.1.

\section{Tab. 1: Motivation by the Group financial scorecard indicators (scale (1) - fully agree, ... (3) - neutral, ...(5) - fully disagree)}

\begin{tabular}{|c|c|c|c|c|c|c|c|c|c|}
\hline \multirow[b]{2}{*}{$\begin{array}{l}\text { Group score card: } \\
\text { Total shareholder } \\
\text { value and Cash flow } \\
\text { from operations: }\end{array}$} & \multicolumn{3}{|c|}{ Men } & \multicolumn{3}{|c|}{ Women } & \multicolumn{3}{|c|}{$\begin{array}{c}\text { High } \\
\text { management }\end{array}$} \\
\hline & $\begin{array}{c}\mathrm{Me} \\
\text { an }\end{array}$ & $\begin{array}{c}\mathrm{Me} \\
\mathrm{dia} \\
\mathrm{n}\end{array}$ & $\begin{array}{c}\text { Std. } \\
\text { De } \\
\text { v }\end{array}$ & $\begin{array}{c}\mathrm{Me} \\
\text { an }\end{array}$ & $\begin{array}{c}\mathrm{Me} \\
\mathrm{dia} \\
\mathrm{n}\end{array}$ & $\begin{array}{c}\text { Std. } \\
\text { De } \\
\text { v }\end{array}$ & $\begin{array}{l}\text { Me } \\
\text { an }\end{array}$ & $\begin{array}{c}\mathrm{Me} \\
\mathrm{dia} \\
\mathrm{n}\end{array}$ & $\begin{array}{c}\text { Std. } \\
\text { De } \\
\text { v }\end{array}$ \\
\hline $\begin{array}{l}\text { I don't feel motivated } \\
\text { by those measures, I } \\
\text { agree to include them } \\
\text { in the scorecard since } \\
\text { they are important } \\
\text { for the Group as a } \\
\text { whole }\end{array}$ & 2.3 & 2.0 & 1.1 & 2.6 & 2.0 & 0.7 & 2.1 & 2.0 & 0.6 \\
\hline $\begin{array}{l}\text { I don't feel motivated } \\
\text { by the above } \\
\text { measures and I } \\
\text { would suggest to } \\
\text { exclude them from } \\
\text { the overall scorecard }\end{array}$ & 3.9 & 4.0 & 1.1 & 3.0 & 3.0 & 1.1 & 3.9 & 4.0 & 1.2 \\
\hline
\end{tabular}

Source: own research and analysis 
Similar outcome of the research is visible as far as the Group environmental indicators are concerned. Majority (53\%) or people are not motivated by those indicators. At the same time, only $13 \%$ of respondents would exclude safety and environmental related indicators from the overall scorecard. People appreciate the need of safety and environment related indicators as part of their overall scorecards, this is visible especially among the answers from the higher managers, where the median is at full disagreement of exclusion. It might be a surprise to some of us, that the overall motivation by safety and environmental indications is higher than motivation by financial indicators. People do care about the environment and safety. Details of the responses are visible in the Tab.2.

Tab. 2: Motivation by the Group environmental scorecard indicators (scale (1) - fully agree, ... (3) - neutral, ...(5) - fully disagree)

\begin{tabular}{|l|c|c|c|c|c|c|c|c|c|}
\cline { 2 - 8 } \multicolumn{1}{l|}{} & \multicolumn{3}{c|}{ Men } & \multicolumn{3}{c|}{ Women } & \multicolumn{3}{c|}{$\begin{array}{c}\text { High } \\
\text { management }\end{array}$} \\
\cline { 2 - 9 } $\begin{array}{l}\text { Group score card: } \\
\begin{array}{l}\text { Safety and } \\
\text { environment related } \\
\text { measures }\end{array}\end{array}$ & $\begin{array}{c}\text { Me } \\
\text { an }\end{array}$ & $\begin{array}{c}\text { Me } \\
\text { dia } \\
\mathrm{n}\end{array}$ & $\begin{array}{c}\text { Std. } \\
\text { De } \\
\mathrm{v}\end{array}$ & $\begin{array}{c}\text { Me } \\
\text { an }\end{array}$ & $\begin{array}{c}\text { Me } \\
\text { dia } \\
\mathrm{n}\end{array}$ & $\begin{array}{c}\text { Std. } \\
\text { De } \\
\mathrm{v}\end{array}$ & $\begin{array}{c}\text { Me } \\
\text { an }\end{array}$ & $\begin{array}{c}\text { Me } \\
\text { dia } \\
\mathrm{n}\end{array}$ & $\begin{array}{c}\text { Std. } \\
\text { De } \\
\mathrm{v}\end{array}$ \\
\hline \begin{tabular}{|l} 
I don't feel motivated \\
by the above \\
measures, I agree to \\
include them in the \\
scorecard since they \\
are important for the \\
Group as a whole
\end{tabular} & 2.7 & 3.0 & 1.3 & 2.2 & 2.0 & 0.9 & 2.9 & 3.0 & 0.8 \\
\hline $\begin{array}{l}\text { I don't feel motivated } \\
\text { by the above } \\
\text { measures and I } \\
\text { would suggest to } \\
\text { exclude them from } \\
\text { the overall scorecard }\end{array}$ & 4.0 & 4.0 & 1.0 & 3.6 & 4.0 & 1.3 & 4.3 & 5.0 & 1.4 \\
\hline
\end{tabular}

Source: own research and analysis

At the moment, the portion of the Group score card indicators to individual scorecard indicators is 1:1. Majority of respondents is neutral to this decision or would reduce the portion of the Group scorecard. 
Also, higher motivation can be achieved if the scorecard is connected to the results of the local operation, rather to the Group as a whole. This is strong opinion of the high management as well as the men's part of the research. In contrary, women are more or less neutral to this statement. See the results in the Tab. 3.

\section{Tab. 3: Motivation by the Group scorecard indicators general (scale (1) - fully agree, ... (3) - neutral, ...(5) - fully disagree)}

\begin{tabular}{|l|c|c|c|c|c|c|c|c|c|}
\cline { 2 - 8 } \multicolumn{1}{l|}{} & \multicolumn{3}{c|}{ Men } & \multicolumn{3}{c|}{ Women } & \multicolumn{3}{c|}{$\begin{array}{c}\text { High } \\
\text { management }\end{array}$} \\
\cline { 2 - 9 } & $\begin{array}{c}\text { Me } \\
\text { an }\end{array}$ & $\begin{array}{c}\text { Me } \\
\text { dia } \\
\text { n }\end{array}$ & $\begin{array}{c}\text { Std. } \\
\text { De } \\
\text { scomments to Grourd part }\end{array}$ & $\begin{array}{c}\text { Me } \\
\text { an }\end{array}$ & $\begin{array}{c}\text { Me } \\
\text { dia } \\
\text { n }\end{array}$ & $\begin{array}{c}\text { Std. } \\
\text { De } \\
\text { v }\end{array}$ & $\begin{array}{c}\text { Me } \\
\text { an }\end{array}$ & $\begin{array}{c}\text { Me } \\
\text { dia } \\
\text { n }\end{array}$ & $\begin{array}{c}\text { Std. } \\
\text { De } \\
\text { v }\end{array}$ \\
\hline $\begin{array}{l}\text { I would suggest to } \\
\text { reduce the weight of } \\
\text { the Group score card } \\
\text { part and increase the } \\
\text { weight of the } \\
\text { individual score part }\end{array}$ & 3.0 & 3.0 & 0.7 & 2.6 & 3.0 & 1.1 & 2.5 & 3.0 & 0.8 \\
\hline $\begin{array}{l}\text { I would feel more } \\
\text { motivated if the } \\
\text { scorecard is based on } \\
\text { the business I work } \\
\text { for, or on the Operat- } \\
\text { ing unit I work in }\end{array}$ & 2.0 & 2.0 & 0.9 & 2.6 & 3.0 & 0.8 & 1.9 & 2.0 & 0.6 \\
\hline
\end{tabular}

Source: own research and analysis

As long as the individual scorecard is concerned, $80 \%$ of people do feel motivated by this, $14 \%$ is neutral and only $6 \%$ claim they do not feel motivated by an individual appraisal. The answers are consistent across all categories of respondents, including men, women and high management. Again, women have higher standard deviation, meaning their answers do vary more when compared to men's ones.

The other question is if the goals set to individuals reflect the quality of the work and more importantly and effort. Vast majority of all respondent thinks they are not. This is in line with the theoretical assumption that is it extremely difficult to observe the effort in the employee versus employer relationship. 
When it comes to the issue, that the individual scorecards are dependent on the subjective appraisal of the line managers, most of the people do not consider this as a de-motivating factor. Men are mostly neutral, women do not mind the subjective valuation at all. Gap between men and women was the biggest when compared to the other answers in the survey. This is in line with the fact that women tend to be more emotional compared to men.

Tab. 4: Motivation by the Individual scorecard measures (scale (1) - fully agree, ... (3) - neutral, ...(5) - fully disagree)

\begin{tabular}{|c|c|c|c|c|c|c|c|c|c|}
\hline \multirow[b]{2}{*}{ Individual scorecard } & \multicolumn{3}{|c|}{ Men } & \multicolumn{3}{|c|}{ Women } & \multicolumn{3}{|c|}{$\begin{array}{c}\text { High } \\
\text { management }\end{array}$} \\
\hline & $\begin{array}{c}\mathrm{Me} \\
\text { an }\end{array}$ & $\begin{array}{c}\mathrm{Me} \\
\mathrm{dia} \\
\mathrm{n}\end{array}$ & $\begin{array}{c}\text { Std. } \\
\text { De } \\
\text { v }\end{array}$ & $\begin{array}{l}\mathrm{Me} \\
\text { an }\end{array}$ & $\begin{array}{c}\mathrm{Me} \\
\mathrm{dia} \\
\mathrm{n}\end{array}$ & $\begin{array}{c}\text { Std. } \\
\text { De } \\
\text { v }\end{array}$ & $\begin{array}{c}\mathrm{Me} \\
\text { an }\end{array}$ & $\begin{array}{c}\mathrm{Me} \\
\mathrm{dia} \\
\mathrm{n}\end{array}$ & $\begin{array}{c}\text { Std } \\
\text { De } \\
\text { v }\end{array}$ \\
\hline $\begin{array}{l}\text { I feel motivated by } \\
\text { individual scorecard } \\
\text { measures }\end{array}$ & 2.0 & 2.0 & 0.7 & 1.9 & 1.5 & 1.3 & 1.8 & 2.0 & 0.7 \\
\hline $\begin{array}{l}\text { I feel motivated by } \\
\text { my detailed KPIs or } \\
\text { individual tasks in } \\
\text { my goal plan, } \\
\text { however they do not } \\
\text { reflect the overall } \\
\text { quality of my work } \\
\text { and effort }\end{array}$ & 2.5 & 2.0 & 1.1 & 2.0 & 2.0 & 0.7 & 2.4 & 2.0 & 0.9 \\
\hline $\begin{array}{l}\text { I am not motivated } \\
\text { by individual score- } \\
\text { card results as they } \\
\text { are too dependent on } \\
\text { the subjective view } \\
\text { of my line manager }\end{array}$ & 3.2 & 3.0 & 1.1 & 3.4 & 4.0 & 1.0 & 2.9 & 3.0 & 0.8 \\
\hline $\begin{array}{l}\text { I am not motivated } \\
\text { by individual score- } \\
\text { card results due to } \\
\text { the fact that my goals } \\
\text { are changing during } \\
\text { the year and its } \\
\text { difficult to prioritize }\end{array}$ & 3.7 & 4.0 & 1.0 & 3.5 & 4.0 & 1.2 & 3.4 & 4.0 & 1.3 \\
\hline
\end{tabular}

Source: own research and analysis 
Last question in this section is trying to evaluate, if the goals and tasks are changing during the year, so it is difficult to set up the proper priorities. The answers are aligned and suggesting that the goals are in fact relatively stable during the year. For some exceptions this might not be the case, as suggested by higher standard deviation. Answers do not differ dramatically when it comes to men, women or higher management. For the individual scorecard results, please see the Tab.4.

There are many other motivating factors, which are not part of the balance scorecard. Some of them had been evaluated as part of the research and are shown in the Tab.5.

Tab. 5: Motivation outside the balance scorecard (scale (1) - fully agree, ... (3) - neutral, ...(5) - fully disagree)

\begin{tabular}{|l|c|c|c|c|c|c|c|c|c|}
\cline { 2 - 9 } \multicolumn{1}{c|}{} & \multicolumn{3}{c|}{ Men } & \multicolumn{3}{c|}{ Women } & \multicolumn{3}{c|}{$\begin{array}{c}\text { High } \\
\text { management }\end{array}$} \\
\cline { 2 - 9 } & $\begin{array}{c}\text { Me } \\
\text { Motivation outside } \\
\text { the balance scorecard }\end{array}$ & $\begin{array}{c}\text { dia } \\
\mathrm{n}\end{array}$ & $\begin{array}{c}\text { Std. } \\
\text { De } \\
\mathrm{v}\end{array}$ & $\begin{array}{c}\text { Me } \\
\text { an }\end{array}$ & $\begin{array}{c}\text { Me } \\
\text { dia } \\
\mathrm{n}\end{array}$ & $\begin{array}{c}\text { Std. } \\
\text { De } \\
\mathrm{v}\end{array}$ & $\begin{array}{c}\text { Me } \\
\text { an }\end{array}$ & $\begin{array}{c}\text { Me } \\
\text { dia } \\
\mathrm{n}\end{array}$ & $\begin{array}{c}\text { Std. } \\
\text { De } \\
\mathrm{v}\end{array}$ \\
\hline $\begin{array}{l}\text { Hearing "thank you" } \\
\text { from my manager } \\
\text { (personally) }\end{array}$ & 1.5 & 2.0 & 0.5 & 1.9 & 1.0 & 1.4 & 1.6 & 2.0 & 0.5 \\
\hline $\begin{array}{l}\text { Being appreciated in } \\
\text { front of my team }\end{array}$ & 2.0 & 2.0 & 1.1 & 3.4 & 4.0 & 1.4 & 2.1 & 2.0 & 1.0 \\
\hline $\begin{array}{l}\text { Special financial } \\
\text { reward, e.g. for a } \\
\text { delivered project }\end{array}$ & 1.3 & 1.0 & 0.6 & 1.3 & 1.0 & 0.7 & 1.1 & 1.0 & 0.4 \\
\hline $\begin{array}{l}\text { Recognition / award } \\
\text { as part of the } \\
\text { competition of the } \\
\text { teams }\end{array}$ & 2.1 & 2.0 & 1.1 & 2.3 & 2.0 & 1.3 & 2.0 & 2.0 & 0.5 \\
\hline
\end{tabular}

Source: own research and analysis

The highest priority has the financial award. 94\% of the respondents do feel motivated by this, remaining $6 \%$ is neutral. Also, the alignment is very high (low standard deviations) across all respondent groups.

Additionally, very powerful motivating factor is a simple word appreciation from the manager. Saying thank you cost nothing and it is apparently motivating $94 \%$ of the respondents. Only remaining $6 \%$ say 
they are not motivated. Although women mostly answered they are motivated, their standard deviation is higher, so their answers are less consistent than those from men.

Appreciation in from of the team can be very tricky as far as the motivation is concerned. Women do not like this at all. This is in contrary to men, where majority feels motivated by such appreciation. Also, people in higher management would be motivated by such appraisal.

Award received as part of the team's competition is also motivating for all respondents groups, however such motivation is less powerful then the individual award.

Other motivating factors had been identified by respondents individually, to name a few, people feel motivated by career opportunities, by training possibilities, by business travel to desired destinations or by additional education options.

Last question related to the yearly employee survey. This survey is executed as part of the stakeholder management and provides the managers and the owners with the view of the employees. Response rate to this survey is constantly high. Also my research indicates that the people consider this survey as useful source of information for the top management. Men are even more positive compared to women. More details are on Tab.6.

Tab. 6: Yearly employee survey

$$
\text { (scale (1) - fully agree, ... (3) - neutral, ...(5) - fully disagree) }
$$

\begin{tabular}{|c|c|c|c|c|c|c|c|c|c|}
\hline \multirow[b]{2}{*}{ Employee Survey } & \multicolumn{3}{|c|}{ Men } & \multicolumn{3}{|c|}{ Women } & \multicolumn{3}{|c|}{$\begin{array}{c}\text { High } \\
\text { management }\end{array}$} \\
\hline & $\begin{array}{l}\mathrm{Me} \\
\text { an }\end{array}$ & $\begin{array}{c}\mathrm{Me} \\
\text { dia } \\
\mathrm{n}\end{array}$ & $\begin{array}{c}\text { Std. } \\
\text { De } \\
\text { v }\end{array}$ & $\begin{array}{c}\text { Me } \\
\text { an }\end{array}$ & $\begin{array}{c}\mathrm{Me} \\
\text { dia } \\
\mathrm{n}\end{array}$ & $\begin{array}{c}\text { Std. } \\
\text { De } \\
\text { v }\end{array}$ & $\begin{array}{c}\mathrm{Me} \\
\text { an }\end{array}$ & $\begin{array}{c}\mathrm{Me} \\
\mathrm{dia} \\
\mathrm{n}\end{array}$ & $\begin{array}{c}\text { Std } \\
\text { De } \\
\text { v }\end{array}$ \\
\hline $\begin{array}{l}\text { I believe that People } \\
\text { Survey is very good } \\
\text { source of information } \\
\text { for the top } \\
\text { management (1) / is a } \\
\text { waste of time for } \\
\text { everybody (5) }\end{array}$ & 1.7 & 2.0 & 0.8 & 2.5 & 2.5 & 1.0 & 2.0 & 2.0 & 1.1 \\
\hline
\end{tabular}

Source: own research and analysis 


\section{Conclusion}

The examined multinational company uses the balanced scorecard, which is based on the global measures as well as on the individual measures. Global measures are split into the financial measures (total shareholder return and operating cash flow) and non-financial measures (environmental related measures).

Results of the research confirmed, that the majority of employees do not feel motivated by global financial results of the whole group. However, at the same time, they understand the importance of those measures for the company as a whole and do feel it is appropriate to leave those global measures in the scorecard.

Slightly better situation is with motivation related to the global environmental measures, where approximately half of the respondents do not feel motivated by the environmental related measures. Vast majority of respondents supports the idea to leave those environmental related indicators within their scorecard. This opinion is the strongest among the higher management. One of the interesting outcomes of this research is that people do care about the environment and safety more than about global financial results as far as the balanced scorecard is concerned.

Company decided to use the same weight for the group scorecard as well as for the individual scorecard. Majority of respondents is neutral to this decision or would reduce the portion of the group scorecard. Higher management as well as men groups would appreciate the scorecard to be connected to the local rather than global results. Women are neutral to this. It is acknowledged that there are advantages and disadvantages to both approaches.

As far as the individual scorecard is concerned, $80 \%$ of respondents feel motivated by this measure. The answers are consistent across all categories of respondents, including men, women and high management.

There is also a strong agreement on the fact, that the individual measurable goals set to employees might not reflect the quality of the work and more importantly and effort. This is in line with the theoretical assumption that is it extremely difficult to observe the effort in the employee versus employer relationship.

The above can be compensated by the individual subjective appraisal of the line manager. It was confirmed by the research, that subjectivity of the appraisal process is widely accepted and most of the people do not 
consider this as a de-motivating factor. Men are mostly neutral; women do not mind the subjective valuation at all.

It was confirmed by the survey, that the goals set to the individuals are relatively stable during the year. This helps to concentrate on the proper priorities and makes the overall appraisal process more straightforward.

It is worth to notice, that there are many other motivating factors, which are not part of the balanced scorecard. $94 \%$ of the respondents would be motivated by hearing thank you from their line manager during their one to one discussion. This powerful motivation cost the company nothing. Interestingly, appreciation in front of the team can be very tricky as far as the motivation is concerned. Women do not like this at all. This is in contrary to men and higher management, where majority feels motivated by such appreciation.

Company is interested in employee opinion and runs a yearly survey as part of the stakeholder management. Response rate to this survey is constantly high. Also my research indicates that people consider this survey as useful source of information for the top management.

The balanced scorecard is applied very consistently in the investigated company over the last 10 years. Also my research confirms that the employees would not like to change this approach dramatically. Perhaps the weight of the group related measures could be slightly reduced and more attention could be paid to the results of the local operations.

\section{References:}

[1] Bichler, U. - Butler, M. (2007): Information Economics. New York. Routledge, 2007.

[2] Kaplan, R. S. (2005): How the Balanced Scorecard Complements the McKinsey 7-S Model. Strategy \& Leadership, 2005, vol. 33, no. 3, pp. 41-46.

[3] Kaplan, R. S. (2010): Conceptual Foundations of the Balanced Scorecard. [on-line], Boston, Harvard Business School Working Papers 10-074, c2010, [cit.: $18^{\text {th }}$ March, 2013], <http://www.hbs.edu/faculty/Publication\%20Files/10-074.pdf>.

[4] Kaplan, R. S. - Norton, D. P. (1992): The Balanced Scorecard Measures that Drive Performance. Harvard Business Review, 1992, vol. 70, no. 1, pp. 71-79. 
[5] Kaplan, R. S. - Norton, D. P. (1993): Putting the Balanced Scorecard to Work. Harvard Business Review, 1993, vol. 71, no. 5, pp. 134-147.

[6] Kaplan, R. S. - Norton, D. P. (1996a): Using the Balanced Scorecard as a Strategic Management System. Harvard Business Review, 1996, vol. 74, no. 1, pp. 75-85.

[7] Kaplan, R. S. - Norton, D. P. (1996b): The Balanced Scorecard: Translating Strategy into Action. Boston, Harvard Business School Press, 1996.

[8] Kaplan, R. S. - Norton, D. P. (2000): Having Trouble with Your Strategy? Then Map It. Harvard Business Review, 2000, vol. 78, no. 5, pp. 167-176.

[9] Kaplan, R. S. - Norton, D. P. (2001): The Strategy Focused Organization: How Balanced Scorecard Companies Thrive in the New Business Environment. Boston, Harvard Business School Press, 2001.

[10] Kaplan, R. S. - Norton, D. P. (2004a): Measuring the Strategic Readiness of Intangible Assets. Harvard Business Review, 2004, vol. 82, no. 2, pp. 52-63.

[11] Kaplan, R. S. - Norton, D. P. (2004b): Strategy Maps: Converting Intangible Assets into Tangible Outcomes. Boston, Harvard Business School Press, 2004.

[12] Kaplan, R. S. - Norton, D. P. (2005): The Office of Strategy Management. Harvard Business Review, 2005, vol. 83, no. 10, pp. 7280.

[13] Kaplan, R. S. - Norton, D. P. (2006): Alignment: Using the Balanced Scorecard to Create Corporate Synergies. Boston, Harvard Business School Press, 2006.

[14] Kaplan, R. S. - Norton, D. P. (2008a): Mastering the Management System. Harvard Business Review, 2008, vol. 86, no. 1, pp. 62-77.

[15] Kaplan, R. S. - Norton, D. P. (2008b): Execution Premium: Linking Strategy to Operations for Competitive Advantage. Boston, Harvard Business School Press, 2008.

[16] Mankiw, N. G. - Taylor, M. P. (2010): Economics. Andover, Cengage Learning, 2010.

[17] Neely, A. -Gregory, M. -Platts, K. (1995): Performance Measurement System Design. A Literature Review and Research Agenda. International Journal of Operations \& Production Management, 1995, vol. 15 , no. 4 , pp. 80-116. 
[18] Neely, A. - Kennerley, M. - Adams, C. (2007): Performance Measurement Frameworks: A review. In Neely, A. (ed.): Business Performance Measurement: Unifying Theories and Integrating Practice. Cambridge, Cambridge University Press, 2007, pp. 143162.

[19] Paranjape, B. - Rossiterand, M. - Pantano, V. (2006): Performance Measurement Systems: Successes, Failures and Future. A Review. Measuring Business Excellence, 2006, vol. 10, no. 3, pp. 4-14.

[20] Petera, P. - Wagner, J. - Menšík, M. (2012): Strategic Performance Measurement Systems Implemented in the Biggest Czech Companies with Focus on Balanced Scorecard. An Empirical Study. Journal of Competitiveness, 2012, vol. 4, no. 4, pp. 67-85.

[21] Saraiva, H. I. B. (2011): The Balanced Scorecard: The Evolution of the Concept and Its Effects on Change in Organizational Management. EBS Review, 2011, vol. 28, pp. 53-66.

[22] Taticchi, P. - Tonelli, F. - Cagnazzo, L. (2010): Performance Measurement and Management: A Literature Review and a Research Agenda. Measuring Business Excellence, 2010, vol. 14, no. 1, pp. 418.

[23] Taticchi, P. - Balachandranand, K. - Tonelli, F. (2012): Performance Measurement and Management Systems: State of the Art, Guidelines for Design and Challenges. Measuring Business Excellence, 2012, vol. 16, no. 2, pp. 41-54.

[24] Tayler, W. B. (2010): Manager's Motivation Related to Business Strategy. Accounting Review, 2010, vol. 85, no. 3, pp. 1095-1117. 


\title{
Motivation of Czech Employees by the Balanced Scorecard of the Multinational Company - an Empirical Study
}

\author{
Barbora JANASOVÁ
}

\begin{abstract}
The aim of this paper is to review if the implemented balanced scorecard is an efficient way to motivate people and increase their work effort. The empirical research had been conducted in one of the big multinational companies. Balanced scorecards for such companies are mainly driven by global, strategic measures. It is questionable, if employees of the Czech local branch are interested and motivated by the global results. Perhaps, it would make more sense to put emphasis on the individual performance measures in this case. Such questions and answers are part of the empirical study conducted for this paper.
\end{abstract}

Key words: Balanced scorecard; Employee motivation; Incentives.

JEL classification: M52, M40. 